\title{
Third World Legal Studies
}

Volume 10 Realizing the Rights of Women in

Development Processes: Women's Legal Entitlements to

Article 9

Agricultural Development and Financial Assistance

$1-9-1991$

\section{An Ecological Perspective on Property Rights in Costa Rica}

Nicole Silk

Follow this and additional works at: http://scholar.valpo.edu/twls

\section{Recommended Citation}

Silk, Nicole (1991) "An Ecological Perspective on Property Rights in Costa Rica," Third World Legal Studies: Vol. 10, Article 9. Available at: http://scholar.valpo.edu/twls/vol10/iss 1/9

This Article is brought to you for free and open access by the Valparaiso University Law School at ValpoScholar. It has been accepted for inclusion in Third World Legal Studies by an authorized administrator of ValpoScholar. For more information, please contact a ValpoScholar staff member at scholar@valpo.edu. 


\title{
AN ECOLOGICAL PERSPECTIVE ON PROPERTY RIGHTS IN COSTA RICA
}

\author{
Nicole Silk*
}

\section{Introduction}

\section{A. Organization and Intent}

This paper presents an analysis of Costa Rican property rights from an ecological perspective. Specifically, this paper reviews the ability of the Costa Rican legal system and property rights regime to incorporate the needs of environmentally sensitive development. ${ }^{3}$ This author, many commentators, ${ }^{2}$ non-governmental organizations, ${ }^{3}$ and the Ministry of Natural

* J.D., University of California, Davis; B.A., Economics and Environmental Studies, University of California, Santa Cruz.

1. Development ideology suggests that countries develop on a linear path toward modernization and progress down this path can be measured in terms of economic growth. W.M. ADAMS, GreEN Development: Environment and SUstainabIITy in the ThIRd World 5 (1990). However, indicators which measure economic growth do not account for the depletion or deterioration in natural resources. World Resources InstiTUte, WorLd Resources 1990-91 243 (1991). Many countries that adopted policies and projects fostering economic growth since the 1950's experienced a deterioration of social and economic conditions. id. Alternative development theories, such as sustainable development, evolved from the failure of orthodox approaches to development. Id. The concept of sustainable development or environmentally sensitive development originated from ecologists' concerns about the long-term consequences of excessive pressure on natural support systems. L.R. BROWN AND E.C. Wolf, Reclaiming the Future, in STATE OF THE WORLD 1988171 (1988).

2. These commentators include Don Perry, renowned tropical forest canopy researcher (interview with Don Perry (Aug. 2, 1991)), Oscar Arias, former president of Costa Rica and Nobel Prize recipient (D.A. Crocker, The Hope for Just, Participatory Ecodevelopment in Costa Rica, in J.R. Engel and J.G. Engel, Ethics of Environment and Development: Global Challenge, INTERNATIONAL RESPONSE 157 (1990)), and Dr. Alvaro Umana, former minister of natural resources for Costa Rica (id. and H. Brough, A New Law of the Land, in World WATCH, Jan.-Feb. 1991, at 19).

3. These non-governmental organizations include Fundacion Neotropica (Fundacton Neotropica, Desarrollo Socioeconomico y el Ambiente Naturai. de Costa Rica 116 (1988)); Center for Environmental and Natural Resource Law of Costa Rica (CEDARENA) (interview with Robert Wells, Co-Director of CEDARENA (July 14, 1991)); Caribbean Conservation Corporation (interview with Bob Carlson (Aug. 2, 1991)); the International Union for the Conservation of Natura (Ministry of Natural Resources, Eneroy and Mines (MIRENEM), Estrategia de Conservacion, para el Desarrollo Sustenible de Costa Rica (ECODES), V (1990)); World Wildlife Fund of the United States (id.); Nature Conservancy (id.); and the University of Costa Rica (id.). 
Resources, Energy and Mines of Costa Rica (MIRENEM) ${ }^{4}$ believe that efforts to maintain a healthy environment necessary for human survival should temper development decisions. ${ }^{5}$ This implies imposing restrictions on land use. ${ }^{6}$ This paper consists of the following sections: an introduction to ecology and development - the justification for land use restrictions; an overview of the origins and development of Costa Rican land tenure patterns; a brief explanation of Costa Rica's legal system and property rights regime; and an analysis of the capacity of the Costa Rican legal system to incorporate land use restrictions necessary for environmentally sensitive development. This author hopes that the reader will gain a better understanding of the ecological impact of development and the legal issues involved in lessening this impact.

\section{B. Introduction to Ecology and Development}

Human survival on earth requires the continuing existence of a suitable environment. ${ }^{7}$ The environment is a huge, enormously complex living machine with interlinked and interdependent parts. ${ }^{8}$ Land is a fountain of energy whose circuits, including soil, plants and animals, adjust to changes within the system..$^{9}$ Accordingly, actions that have an impact on one aspect of the environment reverberate through the entire machine or system. ${ }^{10}$ Because the environment is finite, ${ }^{11}$ ecological limitations will eventually constrain human activities. ${ }^{12}$ The interrelations within, human dependency on, and limitation of the environment give land a paramount role in society. ${ }^{13}$

4. MIRENEM developed and advocates government adoption of the sustainable development strategy for Costa Rica. Id.

5. Supra notes 2, 3, 4 and accompanying text.

6. Land use restrictions can impose ecology's implicit limits on development. Hunter, An Ecological Perspective on Property, 12 Harv. Envtl. L. Rev. 311, 316 (1988).

7. B. Commoner, The Closing Circle: Nature, Man and Technology 14 (1971).

8. Id. at $14-20$.

9. A. Leopold, A Sand County Almanac 216 (1966).

10. B. COMmoner, supra note 7 at 40-41 (describing how everything must go somewhere); Hunter, supra note 6, at 313-14 (defining ecological principles and citing SCIENCE ACtion Coalition with A. Fritsch, Environmental Ethics: Choices for Concerned Citizens 3-4 (1980); W. Berry, The Unsettung of America: Culture and Agriculture 22 (1977); B. Commoner, supra note 7, at 33; Naess, The Shallow and the Deep: Long Range Deep Ecology Movement: A Summary, 16 Inquiry 95 (1973)); and Caldwell, Land and the Law, Problems in Legal Philosophy, 1986 U. IL. L. Rev. 319, 325 (1986) (discussing how human activities on one parcel also impact other parcels).

11. The finite nature of the world is a major ecological tenet. Hunter, supra note 6, at 382 .

12. Id. at 316 (describing the necessity of recognizing ecological limitations).

13. T. Schweigert, Land Tenure Issues in Agricultural Development Projects in Latin America 
Land and the natural resources contained on land represent an available, accessible, and exploitable resource for economic development. ${ }^{14}$ Commonly, logging, agriculture and cattle raising are the predominant methods of exploitation in developing nations. ${ }^{15}$ In Latin America, agriculture is the principle sector of economic activity and often represents the livelihood of a large portion of the population. ${ }^{16}$ Costa Rica is no exception to this general rule. ${ }^{17}$ Agriculture is Costa Rica's primary source of government revenue and foreign exchange earnings. ${ }^{18}$

Development is by its nature an environmentally destructive process. ${ }^{19}$ For example, if present trends continue, estimates suggest that logging, agriculture and cattle raising will destroy all remaining non-protected forests in the developing world by the middle of the next century. ${ }^{20}$ The environmental impact of this conversion include: destruction of wildlife; ${ }^{21}$ loss of genetic diversity; ${ }^{22}$ soil erosion and fertility loss; ${ }^{23}$ environmental contamination; ${ }^{24}$ and global warming. ${ }^{25}$

51 (1989) (available from the University of Wisconsin Land Tenure Center, describing the importance of land and land tenure in Latin America). Land ownership and other secure forms of land tenure are often the only real means for individuals to participate in the political and economic life of their country. J.H. Merryman \& D.S. Clark, Comparative law: Western European and latin American Legal Systems 955 (1978).

14. Agriculture, including cattle raising, is one of the principal sectors of economic activity in developing, compared to developed, countries. E. Trigo, Toward a Strategy for Sustainable Agricultural Development 15 (1991). Land is a primary input for agriculture. T. Schweigert, supra note 13 , at 13 (describing the inputs for agriculture in agricultural economics).

15. E. Trigo, supra note 14, at 5 (explaining the importance of agriculture).

16. J.R. Thome, The Process of Land Reform in Latin America, 1968 WIs. L. REv. 9, 12-15 (1968) (describing the importance of agriculture in Latin America).

17. United States Secretary of the Army, Costa Rica: A Country Profile 133 (1983) (describing the agricultural sector of Costa Rica).

18. Id. at 140 .

19. J. Parsons, The Scourge of Cows: A Special Section on Cultural Geography, in WhOLE Earth Rev., Mar. 22, 1988, at 27 (describing the impact of development on the Third World). Economic growth puts increased pressure on environmental resources and thus causes damage to the environment. The World Commission on Environment and Development, Our Common Future 40 (1987). The exploitation of the earth has gone beyond nature's ability to bounce back. D. Goulet, Development Ethics and Ecological Wisdom, in Engel, supra note 2, at 45-6.

20. D. Perry, Life Above the Jungle Floor 146-47 (1991) citing Peter Raven, director of the Missouri Botanical Gardens (describing the extent of tropical forest destruction).

21. H.J. Leonard, Natural Resources and Economic Development in Central america 153-59 (1987). Habitat loss through changing land use patterns destroys wildlife. Id.

22. Costa Rican flora and fauna are disappearing at alarming rates. Id. at 153-59. Many of the endangered species found in Costa Rica live exclusively outside nationally protected areas. Fundacion NeOtropica, supra note 3, at 14. For instance, 4 of the 45 species of endangered trees 
Forests are a major natural resource of considerable value in Costa Rica, ${ }^{26}$ However, as the most developed country in Central America, ${ }^{27}$ Costa Rica also has a very high rate of deforestation. ${ }^{28}$ In 1977 , only 4,600 square kilometers of forest remained outside nationally protected areas. ${ }^{29}$ Commentators estimate that these privately held forests will vanish within a few years given current rates of deforestation..$^{30}$ The expansion

live outside protected areas; 20 of the 45 species of endangered mammals live outside protected areas; and 12 of the 170 species of endangered birds lives outside protected areas. Id.

23. Id. at 115; W.M. Adams, supra note 1, at 124. When tropical forests are cleared for shortrooted crops or grasses, bases and essential plant nutrients rapidly leach from the soil. J. PARsons, supra note 19, at 22. The top-soil lost due to deforestation may take 100 years to replace. G.M. Guess, Pasture Expansion, Forestry and Development Contradictions: The Case of Costa Rica, 19 Studies in Comparative Latin American Development 47 (1979). However, the forest may not recover for many hundreds of years. J. PARsons, supra note 19, at 27.

24. H.J. Leonard, supra note 21, at 153-59; Fundacion NeOtropica, supra note 3, at 115.

25. Clearing tropical forests adds carbon dioxide previously trapped by the forest cover to the lower atmosphere. L.R. Brown, C. Flavin, and S. Postel, $A$ World at Risk, in State of the World 19898 (1989). This causes warming of the earth's atmosphere or global warming. Id. Global warming may cause tragic changes including the loss of trees, a rise in the level of the sea, the destruction of wetlands, widespread flooding and drought, and the exacerbation of existing environmental stresses. Id. at 10-12.

The environmental impacts of agriculture depend on the type of crop, scale of production, technology used, capacity of the earth to sustain the activity, fertilizer and pesticide use, and economic incentives used by the government to encourage that particular form of agriculture. Fundacion NeOtropica, supra note 3, at 47.

The expansion of pasture lands for cattle destroys wetlands, erodes hillsides, contributes to flooding in flatlands, and causes extensive deforestation. R.G. Williams, ExPort AGriculture aND THE CRISIS IN Costa RICA 115-16 (1986).

26. G.M. Guess, supra note 23, at 42 ; G.M. Guess, Bureaucracy and the Unmanaged Forest Commons in Costa Rica 5 (1979) (presented at the Annual American Society of Public Administrators, Baltimore Maryland (Apr. 1-4, 1979)) (describing the importance of forest resources in Costa Rica).

27. Costa Rica has the highest per capita gross national produce (GNP) in Central America. The World Resources Institute, supra note 1, at 244. GNP measures the total economic activity in a country. Id. at 243. Per capita GNP gives a relative measure of the wealth of a nation's population. Id. Economic activity or growth is the usual indicator of development. See W.M. ADAms, supra note 1.

28. The deforestation rate in Costa Rica was $6.6 \%$ annually between 1940 and 1984 , the highest in Central America. The World Resources Institute, supra note 1, at 42 . The annual rate of deforestation in Latin America as a whole is greater than that of Africa or Asia. Id.

29. Tropical Science Center, Country Environmental Profile 32 (1982). Forest resources located on nationally protected lands receive greater governmental protection than forest resources located on private lands. $I d$. Additionally, the economic self- interests of indjviduals are a greater factor on private lands and increase the potential for deforestation. See generally infra note 31 and accompanying text.

30. Id. at 32. Deforestation may eliminate these resources by the year 2000. D.A. CRocker, supra note 2 , at 157. 
of crop and pasture lands is a major cause of this deforestation. ${ }^{31}$ The environmental impacts of forest conversion in Costa Rica are substantial, reducing the productive capacity of the land, and negatively effecting national development. ${ }^{32}$

The environmental impacts of Third World development affect the capacity of the environment to serve the future needs of humanity. ${ }^{33} \mathrm{High}$ population growth rates in developing countries, including Costa Rica, aggravate these impacts. ${ }^{34}$ However, despite its arguably negative effects, development will continue. ${ }^{35}$ Consequently, the best we can do is minimize the harmful effects of development. ${ }^{36}$ "Sustainable development" embraces this idea of development constrained by the need to protect the environment. Sustainable development promotes economic progress that is ecologically sustainable and satisfies the essential needs ${ }^{37}$ of the entire population. ${ }^{38}$ Essentially, sustainable development fosters development

31. Deforestation is mainly happening on privately owned land and caused by timber, agricultural and cattle-raising activities. E. Lutz and H. Daly, Incentives, Regulations and Sustainable Land Use in Costa Rica, World Bank Working Paper No. 34, 4 (1990) (available through the World Bank Environment Department).

32. G.M. GuEss, supra note 42 (describing the need to protect and develop Costa Rica's forest resources); G.M. GuEss, supra note 26, at 6 (describing the need to protect and develop Costa Rica's forest resources).

33. Human activities which have an impact on natural resources contained on land reverberate through the entire world environment. See B. Commoner, supra note 7, at 34 (explaining the cybernetic nature of ecology). Therefore, the environmental crisis of deforestation and desertification in the Third World affects the entire world. W.M. ADAMS, supra note 1, at 7.

34. E.J. TRIGo, supra note 14 , at 15 . In many parts of the world the population is growing at rates that cannot be sustained by available environmental resources. WORLD CoMmission ON THE Environment AND Development, supra note 19, at 11 (1987). The population of Costa Rica has grown from 801,000 in 1950 (D.S. Clark, Renting, Sharecropping, and Other Indirect Land Tenure Forms in Costa Rica: A Legal and Economic Analysis 33 (1971) (published by the University of Costa Rica Agrarian Law Project)), to 2.4 million in 1984 (Fundacion Neotropica, supra note 3, at 38), and to an estimated 3.5 million by the year 2000 . Id. at 29 . The estimated population density of Costa Rica in the year 2000 will compare to the population density of countries facing severe development problems (India, Bangladesh, Indonesia). Tropical ScIEnce CENTER, supra note 29, at 20 .

35. Development positively effects nations by helping the population satisfy their basic human needs (air, water, food, clothing, shelter, education and medical care) and beyond by increasing their real income or by direct government assistance. D.A. Crocker, supra note 2, at 153-54. However, environmental degradation can undermine economic progress (L.R. BRowN \& E.C. Wolf, supra note 1, at 172), and people continue to use land in ecologically destructive ways. Caldwell, supra note 10, at 322 .

36. J. Parsons, supra note 19, at 27 (describing the inevitability of development).

37. See supra note 35 for a definition of essential or basic human needs. The satisfaction of these needs is often used as a factor to gauge the level of development of a country. Id.

38. W.M. AdAms, supra note 1 , at 2 (defining sustainable development). 
which meets the needs of the present without compromising the ability of future generations to meet their needs. ${ }^{39}$ Sustainable development aims to promote harmony among human beings and between humanity and nature. ${ }^{40}$ This type of development strategy embraces the institutionalization of the human obligation of environmental preservation or a land ethic. ${ }^{41}$

MIRENEM and non-governmental agencies in Costa Rica acknowledge the implicit limit on development imposed by nature and advocate that the Costa Rica government adopt a sustainable development strategy. ${ }^{42}$ The objectives of this strategy include the sustainable utilization of Costa Rica's natural resources, ${ }^{43}$ the preservation of biological diversity, ${ }^{44}$ and the maintenance of essential ecological processes and life support systems..$^{45}$ Implementation of this strategy requires new laws and legal reform, ${ }^{46}$ particularly pertaining to property laws ${ }^{47}$ The following sections provide an analysis of Costa Rican property rights and obstacles to the adoption of a sustainable development strategy. The next section presents an overview of the evolution of the land tenure pattern in Costa Rica, a prerequisite to understanding modern Costa Rican property rights.

\section{The Colonial Inheritance: Land Tenure in Costa Rica}

The Spanish colonists introduced the encomienda system throughout Latin America. ${ }^{48}$ This system consisted of the Spanish Crown entrusting

39. The World Commission on Environment and Devflopment, supra note 19, at 43 (defining sustainable development).

40. Id. at 65 (defining sustainable development).

41. There can be no sound development without ecological wisdom. D. Goulet, supra note 19, at 36. The essential task of development ethics is to assure the painful changes caused by development do not destroy nature, human cultures, individuals, or extract undue sacrifice. Id. Therefore, we must constrain our activities to protect the environment. Id. at 45 . The land ethic imposes an ethical obligation on humans, as members of the environmental community, to take responsibility for protecting the environment. A. LEOPoLD, supra note 9, at 216 . Other commentators have suggested such an institutionalization of a land ethic. See, for example, Caldwell, supra note 10 , or Hunter, supra note 6.

42. See supra notes 3 and 4 , and D.A. Crocker, supra note 2, at 150.

43. MIRENEM defines these natural resources as water, soil, forests, wildlife, etc. MIRENEM, supra note 3, at 1 (unnumbered pages).

44. The term biological diversity includes genetic diversity, species diversity and ecosystem diversity. Id.

45. These processes and systems include nutrient recycling, water source and quality preservation, and the conservation and rehabilitation of soils. Id.

46. Id. at 139-40:

47. H. Brough, supra note 2, at 19 (quoting Dr. Alvaro Umana, Costa Rica's former Minister of Natural Resources).

48. J.R. Thome, Expropriation in Chile Under the FREI Agrarian Reform, 19 Ам. J. Comp. L. 489, 491-93 (1971) (discussing the encomienda system in Chile). 
the lands and peoples of one or more villages in the New World to a particular Spanish colonist. ${ }^{49}$ This individual could use the land and collect taxes and personal services from the local population of Native Americans in return for protecting and Christianizing the Native Americans. ${ }^{50}$ This system resulted in large land holdings and pronounced class differences. ${ }^{51}$ In contrast, the historic development of land tenure patterns in Costa Rica differs from the general pattern in Latin America. ${ }^{52}$ Costa Rica was less rewarding for the Spanish colonists to conquer due to its steep topographic relief, ${ }^{53}$ lack of rich mineral deposits, ${ }^{54}$ and relatively small Native American population to exploit. ${ }^{55}$ The limited Native American population, geographic isolation, and lack of internal agricultural markets prevented the encomienda system from becoming firmly established in Costa Rica. ${ }^{56}$ Consequently, the land tenure pattern that emerged in Costa Rica from the colonial period featured the small family farm and few class differences. ${ }^{57}$

The Spanish Crown gave outright grants to many of the original settlers to use and derive benefit from land within Costa Rica. ${ }^{58}$ Individuals could also acquire land rights by possession under the Spanish law principle of possessory prescription..$^{59}$ Beginning in 1855 , Costa Rican law recognized possessory or squatter's rights to land through a process similar to adverse

49. D.S. Clark, supra note 34 , at 15-16.

50. Id.

51. J.R. Thome, supra note 48 , at 491 (discussing the encomienda system in Chile). The Hacienda system developed from the encomienda. T. Schweigert, supra note 13, at 7 . The resident laborers at the Hacienda usually paid their rent in labor services. Id.

52. C.J. Saenz, Population Growth, Economic Progress, and Opportunities on the Land: The Case of Costa Rica 12 (1969) (unpublished manuscript, submitted in partial fulfillment for a doctorate in philosophy of agricultural economics, University of Wisconsin) (describing Costa Rica's colonial period).

53. Early expeditions from both the Atlantic and Pacific coasts were unsuccessful. D.S. Clark, supra note 34 , at 11 .

54. Id. at 11 (depicting Costa Rica's colonial period).

55. The Native American population of Costa Rica was approximately 27,000 when Christopher Columbus arrived in 1502. Id. at 9-10, citing B. THIEL, Momografia de la Poblacion de Costa Rica en el Siglo XIX, in Rev. de Costa RiCA EN EL Siglo XIX 8 (1902). This population diminished to less than 17,500 by 1563 . S.J. Saenz, supra note 52 , at 12 .

56. Id. at 17 (listing the reasons why the encomienda system did not prosper in Costa Rica).

57. D.S. Clark, supra note 34, at 13-14 (describing Costa Rica's colonial heritage).

58. These land rights did not include the right to exploit Indians as in the encomienda grants and the rights could expire due to land of land use. Id. at 16.

59. Under Spanish law, possessory prescription allows individuals to gain legal title to land occupied and cultivated after the passage of a specific period of time. Id. at 17, citing J. Camacho, Introduccion al Estudio del Derecho Agrario de Costa Rica, in Rev. De CIEnCLAs JuRIDICAs 196-199 (1964). 
possession. ${ }^{60}$ A belief grew from the colonial period that people have a natural right to as much land as necessary for subsistence. ${ }^{61}$ Possibly due to the character of these early property rights, many landowners lack legal title to their land. ${ }^{62}$ Lack of title can make land more difficult to sell or to mortgage for agricultural credit. ${ }^{63}$

Land became more concentrated in larger holdings and class differences became more pronounced beginning in the mid-1800s. ${ }^{64}$ This change coincided with the introduction of new markets, techniques, and equipment

60. C.J. Saenz and C.F. Knight, Titling in Costa Rica: A Legal and Economic Survey, part III, at 1 (1970) (published by the University of Costa Rica Agrarian Law Project). The Costa Rican government originally allowed individuals to gain land rights to public lands by possession through a series of laws encouraging the settlement and dispersal of the population. D.S. Clark, supra note 34, at 29. These laws contained various vesting periods for ownership rights. Id. The government closed public lands to colonization in 1962, though squatters continue to invade these lands. TropICAL SCIENCE Center, supra note 29, at 30.

The government gave squatters additional rights in 1941 to gain title to lands already in private hands. Ley de Informaciones Posesorias, Ley No. 139 (July 14, 1941). Squatters can gain possessory rights to private lands after making improvements to the land and after one year of continuous, public, peaceful and good faith occupation. Civil and Family Code of Costa Rica, arts. 279-286 (4th ed. 1991). The possessory rights may mature into ownership rights after ten years. Id. at art. 860 and Ley de Informaciones Posesorias, Ley No. 139, art. 1 (July 14, 1941). Good faith means that the claimant believed he had the right to possess the land upon entering. Civil and Family Code of Costa Rica, art. 285 (4th ed. 1991). The law presumes good faith. Id. at art. 286.

The laws permitting squatters to gain legal rights to land create problems and are prone to abuse. For example, squatters, in an effort to make improvements to satisfy the legal requirements to acquire land title, clear forest lands for pasture or crop activity. TropiCal SCIENCE CENTER, supra note 29 , at 30 . This contributes to deforestation. Id. Additionally, some squatters claim fraudulent rights in an effort to gain rights to land which can then be sold to other parties. Id. Some commentators advocate legal reform of the laws that encourage squatters to clear the forest in order to fulfill the legal requirements to establish possessory rights. H. Brough, supra note 2, at 19, referring to Dr. Alvaro Umana, former Minister of Natural Resources for Costa Rica. Robert Goodland, staff of the World Bank, advocates similar legal reform in developing countries generally. R. Goodland, Tropical Deforestation: Solutions, Ethics, Religions, World Bank Working Paper No. 33, 16 (1991) (available through the World Bank Environment Department).

61. D.S. Clark, supra note 34, at 19, and C.J. Saenz, supra note 52, at 18-19. Rural Costa Ricans believe the presence of non-producing lands is a crime. T.E. Downing and E.J. Matteson, Squatters: A Form of Spontaneous Colonization in Costa Rica 9 (1965) (available through the Tropical Science Center). This belief may contribute to the lack of respect in rural Costa Rica for property rights on uncultivated or non-producing land.

62. In 1970 between 40 and $80 \%$ of rural farms outside the Meseta Central lacked title. S.J. Saenz and C.F. Knight, supra note 60, part I, at 4-5. The Meseta Central, located in the high valleys in the middle of Costa Rica, is the center of population and economic activity since colonial times.

63. Id. at 9 (explaining the impact of not having recorded title). Deficient land cadastre and registration systems is a common problem throughout Latin America. J.H. MERRYMAN AND D.S. Clark, supra note 13, at 987.

64. G.M. Guess, supra note 23 , at 50. 
for coffee production. ${ }^{65}$ The transformation toward greater land concentration and larger class differences continues today. ${ }^{66}$ Small farms are gradually becoming a phenomenon of the past in many regions of Costa Rica. ${ }^{67}$

\section{The Costa Rican Legal System and Property Rights Regime}

Land rights confer status, wealth and power. ${ }^{68}$ Land rights or the concept of real property is nothing more than a basis of expectation to have a particular relationship with and derive certain benefits from a parcel of land. ${ }^{69}$ The legal regime adopted by each society defines the parameters of this expectation, providing protection through the creation of legal rights. ${ }^{70}$

\section{A. Sources of Law}

Costa Rica is a democratic, ${ }^{71}$ civil law country ${ }^{72}$ with three branches of government. ${ }^{73}$ Written law is the primary source of legal rights in land

65. C.J. Saenz, supra note 52, at 25,28 . Small farmers began selling their farms, in part because they could not afford the capital investment for new equipment and technology required to remain competitive. Id. at 25 .

66. G.M. Guess, supra note 23 , at 50 . The expansion of the cattle industry and pasture lands since the late 1950s also contributed to this transformation. R.G. WILliams, Export Agriculture AND CRISIS IN Central America 77, 99 (1986). In the late 1950s the United States Department of Agriculture (USDA) introduced USDA-approved beef packing plants to Costa Rica. Id. This opened the door for the Costa Rican cattle industry to obtain a larger percentage of the United States beef quota and provided an incentive for the expansion of pasture lands. Id. Large farms absorbed small farms in this quest to expand pasture lands. Id. Government and lending institution policies favoring large over small farmers also contributed to this process. C.J. Saenz and C.F. Knight, supra note 60 , part $\mathrm{V}$, at 6, 9 (discussing the lack of credit available to small farmers). Small farms are often more productive and better credit risks than large farms. G.M. Guess, supra note 23, at 50.

67. Id. (commenting on the plight of the small farmer in Costa Rica); Interview with Agustin Atmetlla, Vice President of CEDARENA and Substitute Costa Rican Supreme Court Justice (Nov. 4, 1991) (discussing patterns of land holdings in Costa Rica).

68. J.M. Merryman and D.S. ClarK, supra note 13, at 955 (describing the importance of land in society). In Latin America, land is even more important than in developed nations because the economy and the population depend heavily on the land for agriculture. T. Schweigert, supra note 13 , at $2-5$.

69. Property is merely a basis of expectation to derive certain advantages from a thing when we are said to possess. J. Bentham, Theory of Legislation, partially reprinted in J.M. Merryman and D.S. ClarK, supra note 13, at 977.

70. Property does not exist but for law. Id. at 978 . Therefore, legal systems define property. Man's use of land takes place within the context of his society's legal system. J.H. Merryman and D.S. ClaRK, supra note 13 , at 955.

71. United States Secretary of the Army, supra note 17, at 185. Costa Rica is a model democracy with a stable government. Id.

72. Costa Rica is a civil law country because the foundation of the legal system is the 
recognized in Costa Rica, and other countries in the civil law or RomanoGermanic tradition. ${ }^{74}$ Stare decisis or judge-made law is generally not a feature of civil law legal systems. ${ }^{75}$ Sources of written law in Costa Rica are the Constitution, ratified international treaties, legislation, executive decrees, and administrative rulings. ${ }^{76}$ The Supreme Court of Costa Rica can declare legislation, executive decrees, or administrative rulings void upon a finding that the law is unconstitutional. ${ }^{n}$

\section{B. Property Rights}

\section{The Civil Law Roots of Property Rights}

The Costa Rican Constitution ${ }^{78}$ and Civil Code $^{79}$ guarantee certain rights in land..$^{80}$ The concepts of property recognized and protected by

72. Costa Rica is a civil law country because the foundation of the legal system is the Napoleonic Civil Code which, in turn, grew out of the Roman jus civile. J.M. MERRYMan and D.S. Clark, supra note 13, at 22 and footnote 19 at 23 (defining the meaning of civil law). Today, Costa Rica's legal system is a modified civil law system due to legal reform of traditional civil law concepts since Independence. Interview with Dr. Rafael Gonzalez Ballar, Professor of Environmental and Agrarian Law at the University of Costa Rica (Nov. 27, 1991).

73. United States Secretary of the ARMy, supra note 17, at 185 . The executive branch has a president, vice-president, and cabinet members. Id. Lawmaking authority rests largely with the legislature or Legislative Assembly, a unicameral body of 57 members elected from the seven provinces of Costa Rica. Id. Judicial authority rests with an independent Supreme Court of Justice and over 100 subordinate courts throughout the country. Id.

74. The Romano-Germanic family of laws is the first family of laws in the world. R. DAvid and J.E. Brierley, Major Legal Systems in the World Today 33 (3d ed. 1985). Civil law refers to the Romano-Germanic family of laws, including the Napoleonic Civil Code. Id. at 22 and note 19, at 23. This family of law spread from Europe to Latin America through the process of colonization. Id. at 23 and 75. Enacted or written law is the primary and almost exclusive source of law today in these countries. Id. at 102 .

The Napoleonic Civil Code is the foundation of the Costa Rican Civil Code. H. Munoz, La Propiedad en el Derecho Constitucional Costarricense, in LA Propiedad 63 (1983). The Costa Rican Civil Code and the Costa Rican Constitution define the property rights recognized by the legal system of Costa Rica. See Civil and Family Code of Costa Rica (4th ed. 1991) and the Political Constitution of the Republic of Costa Rica (1949).

75. T. Schweigert, supra note 13, at 56 (describing the difference in civil law and common law legal systems). However, in Costa Rica, Supreme Court decisions, particularly on issues of constitutional law, may create precedent. Interview with Agustin Atmetlla, Vice-President of CEDARENA and Substitute Costa Rican Supreme Court Justice (Nov. 11, 1991).

76. These sources are listed in hierarchical order of descending significance. Id. and Political Constitution of the Republic of Costa Rica, art. 7 (1949).

77. CEDARENA, Environmental Institutions Study for the World Bank, part II, at 3 (1990) (unpublished study); interview with Agustin Atmetlla, Vice President of CEDARENA and Substitute Costa Rican Supreme Court Justice (Nov. 11, 1991). In 1989, Costa Rican legislators proudly created the Sala Cuarta, a division of the Costa Rican Supreme Court, to specialize in constitutional issues. Imprenta Nacional, Creacion de la Sala Cuarta y Ley de la Jurisdiccion Constitucional 7 (1990). The jurisdiction of the Sala Cuarta includes habeas corpus and constitutional issues. Id.

78. Article 45 of the Costa Rican Constitution contains the property guarantees. Article 45 
the Costa Rican Constitution and Civil Code derive from the French or Napoleonic Civil Code of 1804.81 The Napoleonic Civil Code defined property as the discretionary right to use, enjoy and dispose of land and things associated with the land..$^{82}$ Although some land use regulation existed under the Napoleonic Civil Code, restrictions on private property use was the exception to the general rule. ${ }^{83}$ The Costa Rican Civil Code adopts these principles and defines property as the right to possess, use and derive products from, transfer and transform, defend and exclude others from a specific unit of land. ${ }^{84}$ The Costa Rican Civil Code also grants rights to restitution and indemnification for infringement of these rights. ${ }^{85}$ Additionally, the Costa Rican Constitution guarantees property rights in an absolute manner as inviolable. ${ }^{86}$

\section{Modern Property Rights}

The inviolability of property represents a form of guarantee of personal liberty. ${ }^{87}$ Although the predominant function of property in Costa Rica

states:

Property is inviolable; no one may deprive you of your property unless for a legally declared public interest after indemnification in conformance with the law. In the case of war or internal unrest, the indemnification need not be previous to the loss of the property. However, payment should occur no later than two years after the conclusion of the state of emergency.

For motives of public necessity, the Legislative Assembly may impose limitations of social interest on [private] property through a vote of two-thirds of the total of all Legislative Assembly members.

Political Constitution of the Republic of Costa Rica, Art. 45 (1949).

79. Civil and Family Code of Costa Rica, art. 264-334 (4th ed. 1991).

80. The Costa Rican Constitution states that property is inviolable. Political Constitution of the Republic of Costa Rica, art. 45, I 1 (1949). Under the Costa Rican Civil Code, a property owner has rights to possess, use and enjoy fruits from, transform and alter the subject property. Civil and Family Code of Costa Rica, art. 264 (4th ed. 1991). The property owner may also defend his property, exclude others from its borders, and receive indemnification and restitution for abridgement of property rights. Id.

81. O. Salas and R. Barahona, Derecho Agrario 64-65 (1973) (describing property concepts of Costa Rica).

82. Id. at 65 citing L. Dugutt, Las Transformaciones Generales del Derecho Privado DESDE EL CODIGO DE NAPOLEON 177-81 (discussing rights extending from the Napoleonic Civil Code notions of property).

83. Land use regulation was usually prevented or prohibited by law under the Napoleonic Civil Code. H. Munoz, supra note 74, at 63 (interpreting the Napoleonic Civil Code). However, some regulation of private property rights existed under the Code. Interview with Steve Mack, staff attorney at CEDARENA (Nov. 11, 1991).

84. Civil and Family Code of Costa Rica, art. 284 (4th ed. 1991).

85. Id.

86. Political Constitution of the Republic of Costa Rica, Art. 45, I 1 (1949). See supra note 78 for the text of Article 45 .

87. E.O. Ortiz, Limitaciones Expropiatorias y Limitaciones de Interes Social, in Rev. Judictal 
is to serve the personal and indeterminate interests of the individual, ${ }^{88}$ Costa Rican law does not protect the unlimited or totally self-serving exercise of property rights. ${ }^{89}$ The Costa Rican Constitution contains two other fundamental points pertaining to property rights: $:^{90}$ private property may be expropriated for reasons of public interest; ${ }^{91}$ and the legislature may impose limitations on private property use for reasons of social interest without compensating the property owner for a loss of rights..$^{92}$ These two provisions of the Costa Rican Constitution define and restrict guarantees of property rights under Costa Rican law.

\section{a. Expropriation}

The Napoleonic Civil Code and Costa Rican law allow private property to be expropriated, but only where the deprived party receives indemnification before the expropriation and the expropriation is for a legally declared public interest. ${ }^{93}$ The classic form of expropriation has the effect of transferring something identifiable from the property owner to the state by a public act. ${ }^{94}$ However, expropriation may also occur when a law diminishes or deprives a party of rights even though there is no outright transfer of something identifiable to another party. ${ }^{95}$

\section{b. Limitations}

As stated previously, traditional civil law concepts of property did not tolerate land use restrictions because they are an infringement on the exercise of private property rights. ${ }^{96}$ However, traditional civil law concepts

DE Costa RICA 17, 19 (1985) (explaining concepts contained within Article 45 of the Costa Rican Constitution).

88. Id. at 17 (discussing modern property rights in Costa Rica).

89. Id. at 19 (explaining that Costa Rican law does not fully recognize absolute property notions contained within the Napoleonic Civil Code or that private property rights cannot be regulated or limited).

90. These points are in addition to the fundamental point that property is inviolable.

91. Political Constitution of the Republic of Costa Rica, art. 45, I 1 (1949). See supra note 78 for the text of Article 45 .

92. Id. at art. 45, I 2. See supra note 78 for the text of article 45.

93. Id. at art. 45, I 1; Civil and Family Code of Costa Rica, arts. 316-334 (4th ed. 1991).

94. E.O. ORTIZ, supra note 87 , at 21.

95. Id.

96. Traditional civil law concepts of property contained in the Napoleonic Civil Code specifically prohibit land use regulation. H. MUNoz, supra note 74, at 63 (interpreting the Napoleonic Civil Code). However, limited regulation of private property existed under the Napoleonic Civil Code. Interview with Steve Mack, Staff Attorney at CEDARENA (Nov. 11, 1991). 
of property addressed the needs of a society with fewer people and greater environmental health and integrity. ${ }^{97}$ Notions of property encouraging land exploitation and unrestricted private land development preserve an economic system predicated on the false assumption that all growth is good. ${ }^{98}$ Critics of the Napoleonic Civil Code recognized that absolute, exclusive, and perpetual property rights created by the Code are not appropriate today. ${ }^{99}$ In 1943 , Costa Rica also recognized the shortcomings of the Napoleonic Civil Code concept of property and began allowing limitations of private property for reasons of social interest. ${ }^{100}$ A majority of Latin American nations had already amended traditional civil law concepts of property in a similar fashion by the $1940 \mathrm{s.} .^{101}$

In 1949, Costa Rica ratified a new Constitution. ${ }^{102}$ The Constitution contains language allowing private property limitations, in part to recognize the social function of property ignored by traditional civil law concepts of property. ${ }^{103}$ The second paragraph of Article 45 of the Constitution grants the legislature the authority to impose limitations on the exercise of private property rights for reasons of social interest, after a two-thirds majority vote by the members of the legislature. ${ }^{104}$ The Costa

97. For example, in 1950, Costa Rica had approximately less than one-quarter of its present population. See supra note 34. As population increases, the associated demands on the environment become more complex and intense. P. Ehrlick, A.H. Ehrlick and J.P. Holdren, Ecoscience: Population, Resources, Environment 1 (1977). Therefore, in 1804, the demands of humanity on the environment were less complex and intense.

98. Hunter, supra note 6 , at 378.

99. This concept of property is outdated and inadequate for 20th century needs. J.H. MERRYMAN and D.S. Clark, supra note 13, at 975. See also Constitutional Debates Preceding the Adoption of the Present Constitution, act 104 at 472 (1949).

100. Id., acts 104 and 105.

101. Id., act 104 at $472-76$.

102. Political Constitution of the Republic of Costa Rica (1949). The ratification of the Constitution followed a relatively quiet revolution in 1948. UNITEd States Secretary of the ARmy, supra note 17, at 188. Jose Figueres Ferrer, the President of Costa Rica after the revolution, appointed a constituent assembly to make a national charter. Id. This national charter became the Constitution of 1949. Id.

103. Constitutional Debates Preceding the Adoption of the Present Constitution, acts 104 and 105 (1949). The term the "social function of property" does not appear in Article 45 of the Constitution. Political Constitution of the Republic of Costa Rica, art. 45 (1949). The reformers purposefully chose not to include this term and use instead the term "social interest" because of the socialistic connotations of the former. Interview with Agustin Atmetlla, Vice President of CEDARENA and Substitute Costa Rican Supreme Court Justice (Nov. 12, 1991). The social function of property could abolish private property rights altogether if taken to its logical extreme. Id. This may have caused the reformers to not include the term in the Constitution. Id.

104. Political Constitution of the Republic of Costa Rica, art. 45, 12 (1949). See supra note 78 for the text of article 45 . The constitutional reformers included this second paragraph to the 
Rica Civil Code also allows limitations on private property rights as long as the limitations are legally imposed on or personally agreed to by the property owner. ${ }^{105}$ The social function of property is that land benefits not only private property owners but society as a whole. ${ }^{106}$ The social function of private property allows the ordering of public ends and interests by subordinating the interests of the owner. ${ }^{107}$ Limitations are a method to define the content or the exercise of private property rights. ${ }^{108}$ Consequently, the reformers adopted the definition of property which allows the legislature to impose limitations on private property for reasons of social interest. ${ }^{109}$ However, as in most other countries, the line distinguishing when a regulation becomes an expropriation under Costa Rican law is unclear. ${ }^{110}$

\section{Limiting Private Property Use in Costa Rica}

\section{A. Theoretical Basis for Land Use Limitations}

Our land use demands tax the enviromment."11 The impact of our activities reach beyond the legal boundaries of private property due to the nature of land and natural resources. ${ }^{112}$ The use of private property

Article pertaining to property rights to recognize that in Costa Rica, as opposed to nations that follow the Napoleonic Civil Code more closely, the government has the legal basis to restrict private property rights. Constitutional Debates Preceding the Adoption of the Present Constitution, acts 104 and 105 (1949).

105. Civil and Family Code of Costa Rica, art. 266 (4th ed. 1991) (defining property rights in Costa Rica).

106. Constitutional Debates Preceding the Adoption of the Present Constitution, acts 104 and 105 (1949).

107. E.O. OrTIZ, supra note 87 , at 28 , and Ley No. 11269 (Sept. 30, 1991) (authorizing executive power to expropriate lands in the towns of Turrialba and Jimenez, province of Cartago, for urban growth).

108. Sala Cuarta, proceedings from April 26, 1991.

109. Political Constitution of the Republic of Costa Rica, Art. 45, I 2 (1949).

110. Discussion with Agustin Atmetlla, Vice President of CEDARENA and Substitute Costa Rican Supreme Court Justice (Nov. 12, 1991) (regarding problems in distinguishing between expropriation and regulation of private property). This distinction is also difficult to draw under United States law. Lange, This Land is Whose Land: Changing Concepts of Land as Property, 1973 WIS. L. Rev. 1039, 1048 .

111. In ecology, everything is won at some cost. B. Commoner, supra note 7 , at 46 . Commentators suggest that nature is no longer able to defend and replenish itself from the impact of our exploitation. D. Goulet, supra note 19, at 45.

112. Ecology teaches us that every parcel of land is part of an interconnected web. Hunter, supra note 6 , at 334 . One parcel is inextricably intertwined with other parcels, and therefore causes and effects flow across artificially imposed legal divisions. Lange, supra note 110, at 1045. 
is never an entirely private affair. ${ }^{113}$ Land use restrictions can lessen the environmental impact of our activities by imposing ecological limits on development. ${ }^{114}$ Environmentally sensitive land use regulations impose a legal duty on landowners to refrain from certain environmentally harmful activities. ${ }^{115}$ Accordingly, each landowner has obligations as well as rights extending from his land. ${ }^{116}$ The imposition of this legal duty of wise and responsible land use utilizes law to impose Aldo Leopold's land ethic on humanity. In his exposition of a land ethic, Aldo Leopold suggested that humans have an ethical obligation or duty to take steps, such as restricting land use, necessary to protect and preserve the integrity of the environment. ${ }^{117}$ This obligation arises from human participation in the environment. ${ }^{118}$ Land use restrictions inject this principle of stewardship into property law. ${ }^{119}$ Although landowners may begrudge these restrictions, they also benefit from restrictions imposed on the activities of other landowners. ${ }^{120}$ Commentators promoting sustainable development present similar arguments regarding the restriction of human use of the environment to demonstrate greater respect for nature. ${ }^{121}$

\section{B. The Case of Costa Rica: Imposing a Land Ethic Through Law}

Restricting land use is ecologically logical. However, the historic philosophical foundations of individual property rights deter or inhibit

113. Humback, Law and a New Land Ethic, 74 Mo. L. Rev. 339, 342 (1989) (discussing the activities on one parcel impacting other parcels).

114. Human activities will eventually be constrained by ecological limitations. Hunter, supra note 6, at 314-315. Land use restrictions are the only mechanism for enforcing obligations placed on individual owners by the laws of nature. Id. at 320 .

115. For example, the Legislative Assembly of Costa Rica determined that destroying forest resources was environmentally harmful. Ley Forestal, art. 30. Therefore, property owners may not cut trees or harm forest resources on public or private lands without first obtaining permission from the forestry director. Id.

116. The law must recognize that each landowner has obligations and nonrights as well as rights extending from owning land. Caldwell, supra note 10, at 325 . The land ethic implies that landowners must limit land use as necessary or legally prescribed to protect the environment and cease environmentally harmful activities. Id. at 334.

117. A. LeOPOLD, supra note 9, at 221 (discussing the meaning of a land ethic).

118. Hunter, supra note 6, at 319 (interpreting Aldo Leopold's land ethic). This obligation of stewardship necessarily results from human dependency on a finite environment. Id.

119. To the extent land use restrictions reflect a heightened understanding of the ecological constraints on society they begin to inject Aldo Leopold's land ethic into property law. Hunter, supra note 6 , at 319 .

120. This extends from the theory that all landowners will benefit from an ecologically stable world. Hunter, supra note 6 , at 382.

121. Nature is an object worthy of our respect as well as a resource for future generations. D.A. CRocker, supra note 2, at 158 (discussing the new model of development emerging in Costa Rica). Human intervention can help protect nature for future generations and foster greater respect for nature by limiting human use of the environment. Id. 
the implementation of this ecological logic. ${ }^{122}$ The guarantees of property rights in many legal systems represent the primary obstacle to adopting land use restrictions. ${ }^{123}$ Wise resource use demands that we allow ecologically based land use restrictions and, hence, that we transform our historical legal models and thinking. ${ }^{124}$

The Costa Rica Legislature's constitutional authority to limit property rights for reasons of social interest is also the legal basis for ecologically sensitive land use controls. ${ }^{125}$ The Constitution demands that the government indemnify a private property owner for the loss of property rights where a regulation affecting the property amounts to an expropriation of that property. ${ }^{126}$ Accordingly, ecologically sound land use limitations should not be so great as to constitute expropriation. Hence, the distinction between regulation and expropriation is critical in determining what constitutes lawful, ecologically based land use regulation in Costa Rica.

The classic form of expropriation transfers something identifiable from a property owner to the state through operation of the law, ${ }^{127}$ thereby benefitting the state. ${ }^{128} \mathrm{~A}$ land use regulation should benefit society

122. The concepts of inviolable or absolute property rights in countries of the civil law tradition obstruct and even prohibit the imposition of restrictions on property use. See supra notes 82,83 and accompanying text (regarding property notions extending from the Napoleonic Civil Code).

In the United States, the primary legal obstacle to infringing on property rights is the Fifth Amendment of the United States Constitution. Hunter, supra note 6, at 316. In fact, the Fifth Amendment has been labelled the "major obstacle to effective environmental land use regulation." Id. quoting Note, Developments in the Law - Zoning, 91 HARv. L. Rev. 1427, 1620 (1978).

123. Id.

124. We must transform our historical legal models and thinking because they obstruct imposing land use restrictions on private property. Id., and see supra notes $111-21$, and accompanying text (explaining the theoretical basis for restricting land use). Ecologically based land use restrictions promote wise resource use because they recognize the environment's inherent limitations. Hunter, supra note 6 , at 314-15.

125. Article 45, 12 of the Political Constitution of the Republic of Costa Rica (1949) is the only specific authorization in the Constitution or elsewhere of government power to limit land use in Costa Rica. See supra note 79 for the text of Article 45. Therefore, it is also the legal basis for ecologically sensitive land use limitations in Costa Rica.

126. According to the Constitution, the state may not expropriate private lands unless for a legally declared public interest and only after indemnifying the owner for the loss. See supra note 78 for the text of Article 45. Therefore, if a property owner is deprived of his property without compensation and/or not in accordance with a legally declared public interest, then the regulation is unconstitutional. Interview with Agustin Atmetlla, Vice President of CEDARENA and Substitute Costa Rican Supreme Court Justice (Oct. 31, 1991). If a regulation is unconstitutional, the lawmakers must abandon the regulation or indemnify the owner for their loss. Id.

127. E.O. ORTI2, supra note 87, at 21 (describing expropriation in Costa Rica).

128. The government or its concessionaires benefit from the thing expropriated. E. Espinoza Elizondo, La Expropiacion Forzas, University of Costa Rica School of Law 15 (Feb. 20, 1991). 
generally. ${ }^{129}$ However, as mentioned previously, a law which merely deprives or diminishes private property rights without transferring something identifiable to the state may also be an expropriation. ${ }^{30}$ This second type of expropriation raises the critical question of when does a regulation which, for example, benefits society generally, amount to an expropriation?

\section{Supreme Court Guidance}

The Supreme Court of Costa Rica recently suggested criteria for distinguishing when a regulation becomes an expropriation. ${ }^{131}$ These suggested criteria may create binding precedent in Costa Rica. ${ }^{132}$ According to the Supreme Court and Costa Rican legal scholars, the critical factor in distinguishing between expropriation and regulation is the degree of sacrifice caused to the landowner by the regulation. ${ }^{133}$ The Supreme Court also stated that if a regulation causes private property to be stripped of all market value, causes atypical or especially severe harm, or affects only one person, the regulation is an expropriation requiring indemnification. ${ }^{34}$ This is the first time the Supreme Court has stipulated specific criteria for determining when a regulation amounts to an expropriation. ${ }^{135}$ Assuming that this opinion creates binding precedent, lawful ecologically based land use limitations in Costa Rica should not cause sacrifices such as these. ${ }^{136}$

The constitutional reformers altered the Napoleonic Civil Code notion of absolute property rights to permit limitations of private property rights

129. Id.

130. E.O. ORTIZ, supra note 87, at 21 (describing expropriation in Costa Rica).

131. Sala Cuarta, proceedings from April 26, 1991.

132. As mentioned previously, Costa Rican Supreme Court decisions pertaining to the constitutionality of Costa Rican law may create binding precedent. See supra note 75 , and accompanying text. Supreme Court recommendations or advisory opinions on matters of constitutional significance may also create precedent. Interview with Agustin Atmetlla, Vice President of CEDARENA and Substitute Costa Rican Supreme Court Justice (Nov. 12, 1991). This is an emerging area of Costa Rican law. Id.

133. E.O. Ortiz, supra note 87, at 21; Sala Cuarta, proceedings from April 26, 1991.

134. Sala Cuarta, proceedings from April 26, 1991.

135. Interview with Steve Mack, Staff Attorney at CEDARENA (Nov. 11, 1991); Interview with Agustin Atmetlla, Vice President of CEDARENA and Substitute Costa Rican Supreme Court Justice (Nov. 12, 1991).

136. Additionally, the source of harm or the public harm caused without regulation are not decisive factors in determining when a regulation amounts to an expropriation according to Costa Rican legal scholars. E.O. ORTIz, supra note 87, at 37; Ley No. 11269 (Sept. 30, 1991) (authorizing executive power to expropriate land in the towns of Turrialba and Jimenez, province of Cartago, for urban growth). 
for reasons of social interest. ${ }^{137}$ Unfortunately, the Constitution does not define what it means by limitations of social interest. ${ }^{138}$ However, the intent of the lawmakers in allowing private property limitations for reasons of social interest and recent legislation provide guidance pertaining to what constitutes lawful land use regulation in Costa Rica.

\section{The Intent of the Lawmakers}

Critics of the Napoleonic Civil Code notion of private property believe the Code ignores the social function of property. ${ }^{139}$ The social function of property recognizes society's right to demand more beneficial private property use, even if in contradiction to the desires of the property owner. ${ }^{140}$ According to the constitutional reformers, logical limitations of private property rights in accord with the social function of property would help prevent disorderly and arbitrary land use and foster economic development. ${ }^{141}$

The constitutional reformers did not ultimately adopt language specifically recognizing the social function of property. ${ }^{142}$ However, they did alter traditional civil law concepts of absolute and inviolable property rights. ${ }^{143}$ Arguably, allowing property limitations for reasons of social interest recognizes the social function of property. ${ }^{144}$ Private property limitations control and direct land use by subordinating the landowner's

137. Constitutional Debates Preceding the Adoption of the Present Constitution, acts 104 and 105 (1949).

138. O. Salas and R. Barahona, supra note 81 , at 70 .

139. Constitutional Debates Preceeding the Adoption of the Present Constitution, act 104 (1949).

140. O. SAlAs and R. BARAHONA, supra note 81 , at 65.

141. Constitutional Debates Preceding the Adoption of the Present Constitution, act 104, at 472 (1949).

142. See supra note 103 and accompanying text (explaining why the reformers did not adopt the term social function).

143. The Constitution specifically allows property limitations for reasons of social interest. Political Constitution of the Republic of Costa Rica, Art. 45, I 2 (1949). Under the Napoleonic Civil Code, limiting private property use was generally prohibited except in exceptional cases. See supra note 83 and accompanying text (explaining the general prohibition of land use limitations under the Napoleonic Civil Code).

144. The abuses of private property and profound social inequities led to dissatisfaction and rejection of traditional civil law concepts of property. O. Salas and R. BARAHONA, supra note 81 , at 65 . This evolution caused the recognition of the social function of property or that social interests can be more important than individual interests. Id. Private property limitations for reasons of social interest value society's or social interests above those of the individual. E.O. ORTIZ, supra note 87, at 28 . 
interests to serve public ends and interests. ${ }^{145}$ Environmentally sensitive land use restrictions embody society's demands for wiser land use and environmental protection. Environmental protection should qualify as a social interest basis for restricting land use.

\section{Recent Legislation}

Numerous examples exist of Costa Rican legislation which limit private land use. ${ }^{146}$ These laws include those which pertain to providing public services, urban planning or protecting valuable resources. ${ }^{147}$ Limitations pertaining to the provision of public services include: requiring landowners to cut trees extending over and clear vegetation from land adjoining public roads, ${ }^{148}$ permitting municipal works on land which adjoin public roads to prevent accidents, ${ }^{149}$ allowing electric energy lines and upstream waters to pass across private property, ${ }^{150}$ requiring owners of lands with width greater than twenty meters in urban areas to cede a portion of their lands when necessary for new roads, ${ }^{151}$ and requiring private property owners operating dairy farms to pave unpaved public roads used for the passage of their cattle. ${ }^{152}$

Urban planning became more common after 1968 when the legislature passed a law authorizing municipalities to restrict land uses within their territorial jurisdiction. ${ }^{153}$ However, most municipalities make little use of their urban planning powers. ${ }^{154}$ The law protects historic and artistic resources located on private lands by prohibiting landowners from destroy-

145. E.O. ORTLZ, supra note 87, at 28; Ley No. 11269 (Sept. 30, 1991) (authorizing executive power to expropriate land in the towns of Turrialba and Jimenez, province of Cartago, for urban growth).

146. See infra notes $148-161$ and accompanying text.

147. Laws which pertain to providing public services include allowing public utility workers and projects access to your land and giving the public utility the right to use your land temporarily or permanently. See infra notes 148-152, and accompanying text.

Laws which pertain to urban planning and the protection of valuable resources include authorizing municipalities to plan and restrict land use within their territorial jurisdiction, protecting historic and artistic resources on private lands, and protecting forest and coastal resources. See infra notes 153161 and accompanying text.

148. Ley de Caminos, art. 20.s

149. Ley de Construcciones, art. 11.

150. Ley de Servicios Nacionales de Energia, art. 21, and Ley de Construcciones, art. 94.

151. Ley de Planificacion Urbana, art. 7.

152. Ley de Caminos, art. 19.

153. Ley de Planificacion Urbana, Ley No. 4240, art. 15-78 (1968).

154. Interview with Rodrigo Barahona, Co-Director of CEDARENA and Professor of Agrarian Law (Sept. 26, 1991). 
ing these valuable resources. ${ }^{155}$ Owners of land within the coastal zone must obey government plans pertaining to these lands and obtain permission from the responsible municipality, the National Lands Institute and the Institute of Tourism for any use contemplated within the zone. ${ }^{156}$

Perhaps the most environmentally protective laws pertain to protecting forest resources. The government forbids agriculture within forest zones unless authorized by the director of forestry ${ }^{157}$ and obliges all landowners within forested areas to cede a portion of their land for reforestation. ${ }^{158}$ Finally, the government prohibits all activities which eliminate forest resources, including the cutting of any tree to clear land for pastures or crop cultivation, unless accomplished pursuant to a permit from the director of forestry. ${ }^{139}$ The law requiring government approval before the landowner eliminates forest resources withstood a constitutional challenge. ${ }^{160}$ In declaring this law constitutional, the Supreme Court reasoned that environmental conservation and natural resource protection is a social interest of greater importance than the free exercise of private property rights. ${ }^{161}$

These decisions suggest that the Costa Rican legal system recognizes that environmental protection is a legitimate social interest. ${ }^{162}$ Accordingly, private property rights may be limited to protect the environment as long as the legislative limitations benefit society or a large group of persons do not inflict severe harm on the property owner and do not result in removing the market value of affected private property. ${ }^{163}$

155. Ley de Propiedad Historico o Artistico, art. 4. However, the law allows that landowners with historic or artistic property located on their land may destroy this property for reasons of security. Id.

156. Ley de la Zona Maritima Terrestre, art. 19 and 20.

157. Ley Forestal, art. 47.

158. Ley Forestal, art. 73. This portion need not exceed $5 \%$ of the total land area of the parcel. Id.

159. Ley Forestal, art. 87.

160. CEDARENA, Resumen del Diagnostico Preliminar Para El Taller Sobre Ordenamiento Rural 11 (Sept. 26, 1991) (describing the legal basis and organizational strategy behind imposing a national plan of land use zoning in Costa Rica) referring to Corte Plena proceedings, Ley No. 4465 (May 17, 1984) and Sala Cuarta proceedings, Ley No. 7032 (May 22, 1990).

161. Id. at 11-14.

162. The Legislative Assembly and the Supreme Court recognized that environmental conservation and natural resource protection, including the protection of forest and coastal resources, is a social interest which provides a rationale for imposing land use limitations. Id. A recent unpublished case from the Corte Plena also supports this premise. Interview with Robert Wells, Co-Director of CEDARENA (Dec. 16, 1991). This is an emerging area of Costa Rican law. Id.

163. Ley Forestal, article 87 , provides an excellent example of a lawful and ecologically sound 


\section{Conclusion}

Costa Rica is a model democracy in Latin America ${ }^{164}$ with an impressive history of preserving national lands ${ }^{165}$ and promoting ecologicallyoriented tourism. ${ }^{166}$ Costa Rica is also one of the most biologically diverse nations in the world ${ }^{167}$ However, despite its wealth of natural resources, Costa Rica has enormous environmental problems. ${ }^{168}$ One of the principle causes of Costa Rica's environmental problems is the model of development adopted by the Costa Rican government. ${ }^{169}$ This model has favored economic growth at the expense of natural resources and future generations. ${ }^{170}$

Costa Rica could, however, adopt a different and more environmentally respectful model of development as suggested by commentators, ${ }^{171}$ non-governmental organizations, ${ }^{172}$ and MIRENEM. ${ }^{173}$ Properly conceived,

land use limitation. Ley Forestal, art. 87; and CEDARENA, supra note 160, at 11-14. A land use limitation which falls within the degree of sacrifice of expropriation is unconstitutional. See supra notes 131-36, and accompanying text. Therefore, a lawful, ecologically sound land use limitation should cause less sacrifice than the degree of sacrifice recognized by the Sala Cuarta as an expropriation. Id. Otherwise, the government will need to indemnify the owner for the loss pursuant to the Constitution. Political Constitution of the Republic of Costa Rica, art. 45, I 1 (1949). See supra note 78 for the text of article 45 .

164. United States Secretary of the Army, supra note 17, at 185.

165. R.S. Scheck, Costa Rica: A Natural Destination 5 (1990). National parks and other protected areas comprise almost $30 \%$ of Costa Rica. Id. Costa Rica has international standing in the conservation community for its commitment to preserving forests and wildlife. Id.

166. Costa Rica is an international center for ecotourists. M.A. Boza, Parques Nacionales de Costa Rica 7 (1987).

167. D.A. Crocker, supra note 2, at 157.

168. Id. These environmental problems may be exacerbated by lack of regard to the consequences that flow from particular land uses. Caldwell, supra note 10, at 322.

169. Fundacion Neotropica, supra note 3, at 116. The environment and development are inexorably linked. The World Commission on ENviRonment and Development, supra note 19, at 37. However, professionals in the field of development have only rarely and recently made this link. W.M. ADAMs, supra note 1 , at 8.

170. Fundacion Neotropica, supra note 3, at 116. Costa Rica's development model assumes accelerated growth is worthwhile and that environmental exploitation is a means to the good life, North American style. D.A. CROcKer, supra note 2, at 157-58.

171. See supra note 2 and accompanying text.

172. See supra note 3 and accompanying text.

173. See supra note 4 and accompanying text. Some suggest that a new model of development which incorporates environmental respect or sustainable development is already emerging in Costa Rica. D.A. Crocker, supra note 2 at 150 . Greater sensitivity to the needs of the natural world is beginning to emerge worldwide. T. BerRy, The Dream of THE Earth 212 (1988). For instance, the World Bank is reassessing its previous activities and introducing ecologically viable programs, the Nature Conservancy and other groups are helping protect world resources by managing private nature reserve, and citizens are becoming more aware of the consequences of human activities. Id. at 214 . 
this strategy makes conservation the soldier of development. The Costa Rican legal system, property rights regime, intent of the lawmakers in altering traditional civil law concepts of property to allow land use limitations, and recent legislation suggest that Costa Rica can have ecologically sound land use limitations. ${ }^{174}$ Accordingly, Costa Rica can impose a sustainable development strategy or a land ethic through law. However, to reach this end Costa Rica needs more laws limiting private property use. Certainly, this regulation should not amount to an expropriation. Therefore, the law should not unfairly burden particular landowners or deprive a landowner of all or nearly all exercise of his private property rights. However, this still leaves a substantial margin within which to impose land use restrictions in Costa Rica 